\title{
Endotoxin in storage medium of human corneal grafts and clinical course after penetrating normal- risk keratoplasty
}

H Spelsberg' ', T Reinhard', Y Sokolovska', G Zysk², D Böhringer ${ }^{1}$ and R Sundmacher ${ }^{1}$

\begin{abstract}
Purpose It is well known that endotoxins in storage medium may stimulate cytokine production and expression of adhesion molecules as well as endothelial damage in human corneal grafts. It has been supposed that endotoxin exposure of corneal grafts may, therefore, cause immune reactions and lead to reduced endothelial cell count after penetrating keratoplasty. It was the purpose of this prospective study to evaluate if this

of immune reactions, graft failure, and postoperative endothelial cell counts could not be revealed in patients with normal-risk keratoplasty.

Conclusion Low endotoxin levels in storage medium neither seem to promote immune reactions nor to contribute to postoperative chronic endothelial cell loss in normal-risk keratoplasty patients.

Eye (2004) 18, 923-928. doi:10.1038/sj.eye.6701343

Published online 27 February 2004
\end{abstract} hypothesis is true.

Methods A consecutive series of 274 samples of sterile organ culture storage medium from 274 human corneal grafts was collected between August 1998 and February 1999 and tested for endotoxin using Limulus amebocytelysate assay ( $L A L)$ after 7 days of organ culture. Threshold endotoxin level was set at $1.0 \mathrm{U} / \mathrm{ml}$. A total of 161 grafts were transplanted and 113 were discarded. Within the 161 corneas transplanted, 62 were grafted to normal-risk patients and 99 to high-risk patients. Only normal-risk keratoplasty patients were included in the study and followed for at least $\mathbf{1 0}$ months. Immune reactions, graft failures, and postoperative endothelial cell counts were recorded.

Results The mean endotoxin level in organ culture medium of all transplanted grafts was $1.07 \pm 2.96$. Mean endotoxin level in organ culture medium of discarded grafts was $1.68 \pm 5.76$, with 71 samples being below and 42 above the threshold of $1.0 \mathrm{U} / \mathrm{ml}$ called endotoxin-negative and endotoxin-positive, respectively. In all 36 culture medium samples from the $\mathbf{6 2}$ grafts transplanted to the group of normal-risk keratoplasty patients were endotoxin-negative and 26 endotoxin-positive. An influence of endotoxin levels on incidence
Keywords: Lipopolysaccharides/endotoxin; corneal organ culture; normal-risk penetrating keratoplasty; clear graft survival

\section{Introduction}

Endotoxins are biologically active

lipopolysaccharides, which are integral components of the cell wall of gram-negative bacteria. These molecules are found exclusively in the outer lipid membrane of the bacterial cell wall. They exhibit only toxic effects if not membrane-bound. The term endotoxin was introduced historically, when Vibrio cholerae and its two different types of toxin were detected in the end of the 19th century: endotoxin as a heatstable toxin released by disintegration - and also by viable pathogens during the log phase or under suboptimal nutrition ${ }^{1}$ - and exotoxin as a heat-labile toxin released during growth of Vibrio species.

Endotoxins themselves have little toxicity, but they trigger local and systemic inflammatory responses by interacting with several humoral and cellular mechanisms. ${ }^{2}$ They stimulate the release of cytokines and, systemically, the activation of complement system, fibrinolytic,
${ }^{1}$ LIONS Cornea Bank NRW and Eye Hospital Heinrich-Heine-University Duesseldorf

Germany

${ }^{2}$ Department of Medical Microbiology and Virology Heinrich-Heine-University Duesseldorf Germany

Correspondence:

H Spelsberg LIONS Cornea Bank NRW and Eye Hospital Heinrich-Heine-University Moorenstrasse 5 Duesseldorf, 40225 Germany Tel: + 492118117320 Fax: +492118116241

E-mail: spelsber@

uni-duesseldorf.de

Received: 20 September 2002

Accepted: 24 January 2003

Published online:

27 February 2004

This work has been presented at the Annual Meeting of the European Eye Bank Association in January 2001. 
and coagulative cascades. In large quantities, this leads to irreversible vascular damage, shock or multiple organ failure. $^{2}$

In vivo, the corneal endothelium is protected from exposure to endotoxins by the epithelial and vascular barriers. When corneal grafts are kept in organ culture medium, such barriers do not exist. Since in vivo the cornea is part of the body surface and, therefore, contaminated with bacteria, even the carefully disinfected corneal graft carries few of them over into the primary organ culture medium, ${ }^{3,4}$ which is supplemented with antibiotics according to the standards of the European Eye Bank Association. ${ }^{5}$ Therefore, contamination with replicating and, moreover, more commonly gram-positive pathogens is extremely rare. ${ }^{6}$ Nevertheless, nonreplicating or disintegrating bacteria may be present releasing lipopolysaccharides: these have been detected, irrespective of the storage technique, in microbiologically sterile organ culture media in up to $50 \% .^{7,8}$

It has been shown that endotoxins stimulate the secretion of interleukins in human corneal cells. ${ }^{9}$ IL-1 mediates inflammatory responses in the corneal epithelium, ${ }^{10}$ while both IL-1 and tumour necrosis factor alpha stimulate the expression of IL- 8 mRNA in corneal stromal and endothelial cells. ${ }^{11}$ Increased amounts of IL-6 are found in corneal epithelial, stromal, and endothelial cells after exposure to endotoxins. ${ }^{12}$ When human corneal grafts were stored in organ culture medium, which was experimentally incubated with high levels of endotoxin $(25000 \mathrm{U} / \mathrm{ml})$, they showed polymorphism and significant endothelial cell loss with increased levels of IL- 8 and IL- 6 in the organ culture medium. ${ }^{9}$ This effect could also be demonstrated for cultured porcine corneal endothelial cells which were incubated with high levels of endotoxin. They showed morphological cell changes and delayed proliferation. ${ }^{13}$ It remains unknown, if this observation is caused by a conventional inflammatory response in vitro or not.

As lipopolysaccharides directly trigger some kind of inflammatory responses in organ-cultured corneal grafts, endotoxin exposure to human corneal grafts during storage in organ culture may cause an elevated risk for immune reactions and accelerated endothelial cell loss after penetrating keratoplasty. Therefore, we prospectively examined a consecutive series of sterile organ culture media for the presence of endotoxin and investigated if endotoxins in the media associate with an elevated risk for immune reactions and graft failure or accelerated endothelial cell loss after penetrating keratoplasty. In order to exclude an influence of epithelial disorders, herpetic recurrences or glaucoma on the study outcome only normal-risk keratoplasty patients were included in the study.

\section{Patients and methods}

\section{Graft storage}

Between August 1998 and February 1999, 274 consecutive samples of microbiologically sterile organ culture medium from 274 human corneal grafts were collected. All corneal grafts were obtained by in situ corneoscleral excision. ${ }^{14}$ Grafts were stored in organ culture medium containing minimal essential medium supplemented with $100 \mathrm{IU} / \mathrm{ml}$ penicillin, $100 \mu \mathrm{g} / \mathrm{ml}$ streptomycin, $2.5 \mu \mathrm{g} / \mathrm{ml}$ amphotericin B, and $2 \%$ foetal calf serum (FCS). Storage time was 10-14 days. After 7 days of storage organ culture medium was exchanged. A $5 \mathrm{ml}$ sample from the primary culture medium was tested for microbiological contamination by loading a vented and a nonvented bottle with fluid agar containing active charcoal, which were then incubated at $+37^{\circ} \mathrm{C}$ and continuously measured photometrically. ${ }^{15,16}$ If an increased flare was observed, the medium sample was spread out on culture plates, incubated, and assessed for growth of pathogens. For this study, only sterile organ culture media were used.

Endothelial cell morphology was evaluated after 7 days of storage and before transplantation using phasecontrast microscopy. Intercellular border swelling, pleomorphism, and cell enlargement were taken into account, while the grafts were immersed in hypotonic buffered saline. Cell density was ascertained by polaroid photography and fixed-frame calculation. Only corneas with an endothelial cell density $>2000$ cells $/ \mathrm{mm}^{2}$ were transplanted.

\section{Endotoxin detection}

At the time of medium exchange, a $1.5 \mathrm{ml}$ sample of primary culture medium was preserved and frozen at $-20^{\circ} \mathrm{C}$, until detection of endotoxin was performed using the Limulus amebocyte-lysate assay (LAL). ${ }^{17,18}$ All samples were tested with the QCL-1000 chromogenic LAL assay (BioWhittaker, Walkersville, MD, USA) by the same person (YS), using the microtiter plate method and LAL from the same batch. Moreover, samples of fresh organ culture medium and FCS alone and mixed together before contact to corneal grafts were also tested.

The biochemical basis for this assay is the activation by bacterial endotoxin of the clotting cascade of Limulus polyphemus, the horseshoe crab. ${ }^{17,18}$ An activation results in general intravascular coagulation and consequent death. ${ }^{17,18}$ The crab's coagulation factors located intracellularly within the sole circulating blood cell, the amebocyte, can be obtained in unactivated form. ${ }^{17,18}$ Activation of amebocyte lysate by incubation with endotoxin leads to polymerization of the clottable protein, which is used in the LAL assay as visible end 
point. ${ }^{17,18}$ The amount of endotoxin determines the initial rate of activation. Then, the splitting of the dye $p$ nitroaniline (pNA) from its colorless substrate is catalyzed by the activated enzyme and its amount is measured photometrically at $405 \mathrm{~nm} .{ }^{8}$ The LAL assay is highly sensitive and is able to detect traces of endotoxins between 5 and $10 \mathrm{pg} / \mathrm{ml}$ resp. $0.005 \mathrm{U} / \mathrm{ml} .^{9}$ It allows only relative measurement of biological activity, not distinguishing between small quantities of highly active or large quantities of low active endotoxin. ${ }^{8}$ The endotoxin concentration was calculated as described before. ${ }^{8,9}$ A medium sample was considered endotoxinpositive, when the concentration was $\geq 1.0 \mathrm{U} / \mathrm{ml}$.

\section{Keratoplasty patients and donors}

Between August 1998 and February 1999, 161 penetrating keratoplasties were performed. A total of 62 (38.5\%) were normal-risk keratoplasties, that is, first keratoplasties in eyes without corneal vascularization, with central graft position, without a preoperative history of severe surface disorders, herpetic eye disease or glaucoma. The mean follow-up time was 18.6 months (10-23). The mean patient age ( 35 women, 27 men) was 55 years (13-87). In all, 99 (61.5\%) were high-risk keratoplasties. Exclusively, the group of normal-risk patients was evaluated for immune reactions, clear graft survival, and endothelial cell count in order to investigate the possible influences of endotoxin levels at best. In comparison to the normalrisk group, the mean donor age (23 women, 39 men) was 60 years $(8-90)$.

\section{Surgical technique and follow-up}

Graft trephination, mostly with a diameter of $7.7 \mathrm{~mm}$, was performed from the endothelial side. The host cornea was trephined with a $0.2 \mathrm{~mm}$ smaller diameter from the epithelial side. The corneal graft was sewn in with a double-running cross stitch nylon 10.0 suture according to Hoffmann. ${ }^{19}$ Preoperatively, no treatment was given at all. Postoperatively, all patients were treated with systemic steroids (fluocortolone $1 \mathrm{mg} / \mathrm{kg}$ body weight) tapered off within 3 weeks, with topical antibiotics (gentamicin $0.5 \%$ ointment) five times daily for 1 week and with topical steroids (prednisolone-21acetate $1 \%$ eye drops) five drops daily tapered off within 5 months. ${ }^{20}$ No additional systemic immunosuppression was administered. Clinical controls were scheduled after 4 and 12 months postoperatively and then annually. The first running suture was removed not before the fourth postoperative month, the second one not before the 18th postoperative month.

\section{Endothelial evaluation and statistical analysis}

Endothelial evaluation was performed postoperatively using a specular microscope (Konan Noncon Robo 800). ${ }^{21}$ This system enables the investigator to calculate semiautomatically the central endothelial cell density in a reliable and correct way. ${ }^{21}$ At least 15 cells were entered in the semi-automatic cell density algorithm of the Robo Noncon for each photograph. ${ }^{21,22}$ For analysis of the postoperative endothelial cell loss, we used the endothelial cell counts after 4 and 12 months (difference between cell counts after the 4 th and after 12th months divided through cell count after the 4th month) per patient.

Statistical analysis was performed using SPSS 10. Testing for interdependence of frequency data was done using exact Fisher test if applicable or else the $\chi^{2}$-test. Metrical data were compared by means of the classic two-sided $t$-test for independent samples.

\section{Results}

Stored at +6 and $+34^{\circ} \mathrm{C}$, all samples of fresh organ culture medium were endotoxin-free. FCS alone, however, revealed a level of $102 \mathrm{U} / \mathrm{ml}$ endotoxin stored at $+6^{\circ} \mathrm{C}$ and of $59 \mathrm{U} / \mathrm{ml}$ stored at $+34^{\circ} \mathrm{C}$. The mixture of organ culture medium and $2 \%$ FCS, respectively, revealed a level of $6.5 \mathrm{U} / \mathrm{ml}$ stored at $+6^{\circ} \mathrm{C}$ and $0.6 \mathrm{U} / \mathrm{ml}$ at stored $+34^{\circ} \mathrm{C}$. Due to negliglible biological activity of traces of endotoxin and due to the detection limit of the test used in this study, the threshold for positive endotoxin contamination was set at $1.0 \mathrm{U} / \mathrm{ml}^{17,18}$

A total of 274 consecutive medium samples of 274 human corneal grafts were investigated. All samples were proven to be microbiologically sterile. In all, 161 grafts were transplanted and 113 corneas were discarded (Figure 1). The discarding reasons were positive or unconclusive serology $(7 ; 6 \%)$ and endothelial damage $(106 ; 94 \%)$. In total, $71(62.8 \%)$ media of 113 discarded grafts were tested endotoxin-negative (level $<1.0 \mathrm{U} / \mathrm{ml}$ ) and $42(37.2 \%)$ endotoxin-positive. In comparison, 100 $(62.1 \%)$ medium samples of 161 transplanted grafts revealed levels below $1.0 \mathrm{U} / \mathrm{ml}$ and 61 (37.9\%) levels

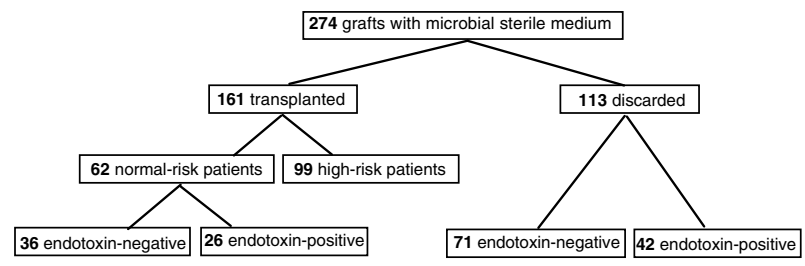

Figure 1 Endotoxin-positive ( $\geq 1.0 \mathrm{U} / \mathrm{ml})$ and endotoxinnegative $(<1.0 \mathrm{U} / \mathrm{ml})$ media of transplanted and discarded corneal grafts. 
above the threshold ( $P=0.54$; Table 1$)$. The mean endotoxin level for transplanted grafts was $1.07 \pm 2.96 \mathrm{U} /$ $\mathrm{ml}$ and for discarded grafts $1.68 \pm 5.76 \mathrm{U} / \mathrm{ml}$ without statistically significant difference $(P=0.25$; Table 1$)$. For patients with normal-risk keratoplasty, the mean endotoxin level was $1.13 \pm 3.37$ with 36 (58.1\%) below and $26(41.9 \%)$ above $1.0 \mathrm{U} / \mathrm{ml}$.

During a mean follow-up time of 18.6 months, $3 / 36$ (8\%) immune reactions were observed in the endotoxinnegative group in comparison to $2 / 26(8 \%)$ in the endotoxin-positive group ( $P=0.65$; Table 2$)$. Regarding clear graft survival, one irreversible graft failure was ascertained in each group $(1 / 36 ; 3 \%$ resp. $1 / 26 ; 4 \%$; $P=0.35$; Table 2). Mean postoperative endothelial cell loss, monitored between the 4th and 12th postoperative months, averaged $17.9 \%$ in the endotoxin-negative group and $13.1 \%$ in the endotoxin-positive group $(P=0.24$;

Table 2). There was no statistically significant association between endotoxin levels and the rate of immune reaction, rate of irreversible graft failure, and mean postoperative endothelial cell loss (Table 2). For all patient, donor, and graft parameters (mean patient age, patient gender, mean donor age, donor gender, mean follow-up, mean post-mortem time, mean organ culture time, and mean preoperative endothelial cell counts), no statistically significant difference between the endotoxinpositive and the endotoxin-negative group was shown either (Table 3).

\section{Discussion}

The aim of this study was to estimate the influence of endotoxin levels in sterile organ culture media of human corneal grafts on the incidence of immune reactions, irreversible graft failure and especially chronic endothelial cell loss after penetrating keratoplasty.

Chronic endothelial cell loss, a decrease of endothelial cell density in the absence of any clinically evident

Table 1 Proportion of endotoxin levels in transplanted and discarded grafts

\begin{tabular}{lccl}
\hline & Transplanted grafts $(\mathrm{n}=161)$ & Discarded grafts $(\mathrm{n}=113)$ & P-value \\
\hline Endotoxin level $<1.0 \mathrm{U} / \mathrm{ml}$ & $100(62.1 \%)$ & $71(62.8 \%)$ & NS $(0.5)$ \\
Endotoxin level $\geq 1.0 \mathrm{U} / \mathrm{ml}$ & $61(37.9 \%)$ & $42(37.2 \%)$ & \\
Mean endotoxin level $(\mathrm{U} / \mathrm{ml}) \pm \mathrm{SD}$ & $1.07 \pm 2.96$ & $1.68 \pm 5.76$ & NS (0.25) \\
\hline
\end{tabular}

Transplanted and discarded corneal grafts and the association to endotoxin levels are given in the above table. SD: standard deviation; NS: not significant.

Table 2 Clinical parameters after keratoplasty and endotoxin levels

\begin{tabular}{|c|c|c|c|}
\hline & Endotoxin level $<1.0 \mathrm{U} / \mathrm{ml}$ & Endotoxin level $\geq 1.0 \mathrm{U} / \mathrm{ml}$ & P-value \\
\hline Immune reactions $(n)$ & $3 / 36(8 \%)$ & $2 / 26(8 \%)$ & NS (0.65) \\
\hline Irreversible graft failure $(n)$ & $1 / 36(3 \%)$ & $1 / 26(4 \%)$ & NS (0.35) \\
\hline $\begin{array}{l}\text { Mean postop. endothelial cell loss between } \\
\text { 4th and 12th month }(\%) \pm \text { SD }\end{array}$ & $17.9 \pm 13.8$ & $13.1 \pm 12.6$ & NS (0.24) \\
\hline
\end{tabular}

Immune reactions, irreversible graft failure, mean postoperative cell loss, and the association to endotoxin levels are shown above. SD: standard deviation; NS: not significant.

Table 3 Donor and recipient data and endotoxin levels

\begin{tabular}{|c|c|c|c|}
\hline & Endotoxin level $(<1.0 \mathrm{U} / \mathrm{ml})$ & Endotoxin level $(\geq 1.0 \mathrm{U} / \mathrm{ml})$ & P-value \\
\hline Mean patient age (years) & 52.5 & 58.6 & NS $(0.27)$ \\
\hline \multirow[t]{2}{*}{ Patient gender } & Female 21/36 (58\%) & Female 14/26 (54\%) & NS (0.46) \\
\hline & Male $15 / 36(42 \%)$ & Male $12 / 26(46 \%)$ & \\
\hline Mean follow-up (months) & 18.3 & 19.0 & NS (0.44) \\
\hline Mean donor age (years) & 57.8 & 61.9 & NS (0.42) \\
\hline \multirow[t]{2}{*}{ Donor gender } & Female $11 / 36(31 \%)$ & Female $12 / 26(46 \%)$ & NS (0.16) \\
\hline & Male $25 / 36(69 \%)$ & Male $14 / 26(54 \%)$ & \\
\hline Mean post-mortem time (hours) & 23.9 & 20.1 & NS $(0.48)$ \\
\hline Mean organ culture time (days) & 18.0 & 17.5 & NS $(0.61)$ \\
\hline Mean preoperative endothelial cell counts (cells $/ \mathrm{mm}^{2}$ ) & 2278 & 2260 & NS $(0.70)$ \\
\hline
\end{tabular}

Patient, donor, graft variables, and the association to endotoxin levels are shown. NS: not significant. 
immune reaction, is routinely observed after penetrating keratoplasty. ${ }^{22-25}$ Regarding the study of Ruusuvaara, ${ }^{26}$ some kind of subclinical immune reaction, not visible at the slitlamp, may be suspected causative. In a homogenous group of patients after normal-risk keratoplasty, increased post-mortem time and advanced donor age were shown to have a significant negative effect on chronic endothelial cell loss. ${ }^{22}$ Regarding storage techniques, no significant difference in chronic endothelial cell loss was found among cold storage $\left(+4^{\circ} \mathrm{C}\right)$ and organ culture $\left(+34^{\circ} \mathrm{C}\right)$ up to 10 years after penetrating keratoplasty in a large longitudinal cohort study. ${ }^{23,25}$

The influence of organ culture media on clinical outcome after penetrating keratoplasty has not yet been investigated. In vitro studies revealed metabolic changes of corneal tissues by various preservation protocols. ${ }^{27,28}$ The composition of the organ culture medium, which has been optimized and standardized for corneal cell and organ culture, may play an important role. ${ }^{29}$ Besides, endotoxins, probably derived from nonreplicating and disintegrating bacteria from the tissue surface, ${ }^{4}$ may alter the corneal graft and, therefore, contribute to accelerated chronic endothelial cell loss. Since replication and disintegration of pathogens under cold-storage conditions is reduced in contrast to organ culture, less release of potentially damaging endotoxin may be assumed. However, the advantage of organ culture conditions regarding pathogen detection seems to be more important for the fate of the corneal graft. In this study, even in FCS and in FCS-supplemented organ culture medium without any contact to corneal buttons, low contents of endotoxin were detected. Surprisingly, these were different dependent on the sample temperature before freezing. We hypothesize that free endotoxin adheres more likely to a surface at a higher temperature and, therefore, lower levels of free endotoxin were detected at $+34^{\circ} \mathrm{C}$ in contrast to $+6^{\circ} \mathrm{C}$.

Sobottka Ventura et al. found increased endothelial cell damage in organ-cultured human corneal grafts after incubation with high levels of endotoxin $(25000 \mathrm{U} / \mathrm{ml}){ }^{9}$ Endotoxin-mediated damage was also observed in cultured porcine corneal endothelial cells, but supplementation with FCS could modulate this toxic effect. ${ }^{13}$ FCS supports the metabolic situation for the endothelium and protects the cornea in some way from damage. ${ }^{13}$ In opposite to the standard organ culture conditions with an FCS content of $2 \%$, the study demonstrated and recommended improved protection from endotoxin-mediated cell damage with an FCS content of $10 \% .{ }^{13}$ Even with endotoxin-contaminated FCS, we suggest the protective mechanism of FCS to be much stronger than any potential damage by very low endotoxin levels, as found in this study $(102 \mathrm{U} / \mathrm{ml})$.
Moreover, endotoxin-incubated organ culture media showed an increase in the level of IL-8 and IL-6, which proved stimulation of the autocrine function of human corneal grafts by endotoxin. ${ }^{9}$ The increase in the levels of IL- 6 and IL- 8 appeared to be correlated with endothelial cell loss. ${ }^{9}$ It may lead to an expression of HLA class II antigens $^{30}$ and, thus, a higher primary immunogeneitiy of the graft with subsequent elevated risk of immune reactions after penetrating keratoplasty.

Little is known about the amount of endotoxin that leads to detectable endothelial cell damage in organcultured corneal grafts. The endotoxin concentration experimentally chosen was $25000 \mathrm{U} / \mathrm{ml}$, which caused high endothelial cell loss and marked morphological changes in human corneal grafts. ${ }^{9}$ Various endotoxin concentrations, ranging between 6250 and $25000 \mathrm{U} / \mathrm{ml}$, did not have any influence on cell counts of aliquots of cultured porcine corneal endothelial cells. ${ }^{13}$ Regarding endotoxin levels found in sterile organ culture media under standard cornea bank conditions, it was observed that the mean levels ranged between 0.35 and $0.75 \mathrm{U} / \mathrm{ml}$, irrespective of the storage technique. ${ }^{7,8}$ In comparison, the mean endotoxin levels detected in our study were slightly higher $(1.07-1.68 \mathrm{U} / \mathrm{ml})$. It is obvious that endotoxin levels which experimentally led to marked endothelial cell damage were at least five log units higher than those found in sterile organ culture media under standard cornea bank conditions: the antibiotics added to organ culture medium effectively avoid remarkable pathogen proliferation and, therefore, release of endotoxin. It was demonstrated that these low endotoxin levels had no influence on the discarding rate and preoperative endothelial cell counts of corneal grafts before surgery.

In order to determine the influence of these endotoxin levels on clinical parameters, a homogenous group of patients with low risk for immune reactions and without additional damaging influences on the graft endothelium was investigated for at least 10 months after penetrating keratoplasty. No statistically significant association was found between endotoxin levels and postoperative endothelial cell counts, the rate of immune reaction, and clear graft survival.

In summary, low endotoxin levels detected in microbiologically sterile organ culture media under standard cornea bank conditions do not seem to contribute to chronic endothelial cell loss or to promote immune reactions after penetrating normal-risk keratoplasty.

\section{References}

1 Tesh VL, Morrison DC. The interaction of Escherichia coli with normal human serum: factors affecting the capacity of 
serum to mediate lipopolysaccharide release. Microbiol Pathogen 1988; 4: 175-187.

2 Movat HZ, Cybulsky MI, Colditz IG et al. Acute inflammation in gram-negative infection: endotoxin, interleukin-1, tumor necrosis factor, and neutrophils. Fed Proc 1987; 46: 97-104.

3 Sperling S, Sorensen IG. Decontamination of cadaver corneas. Acta Ophthalmol 1981; 59: 126-133.

4 Hagenah M, Winter R. Dekontamination menschlicher Spenderhornhäute während der Präparation und Konservierung. Klin Monatsbl Augenheilkd 1996; 209: 1-6.

5 European Eye Bank Association Directory. 9th ed 2001.

6 Hagenah M, Böhnke M, Engelmann K, Winter R. Incidence of bacterial and fungal contamination of donor corneas preserved by organ culture. Cornea 1995; 14: 423-426.

7 Sobottka Ventura AC, Pels E, Engelmann K, Richard G, Böhnke M. Detection of endotoxin in media from sterile corneal organ culture. German J Ophthalmol 1997; 5: 404-407.

8 Sobottka Ventura AC, Böhnke M. Bacterial Lipopolysaccharides in sterile corneal organ-culture media. Cornea 1999; 18: 92-97.

9 Sobottka Ventura AC, Engelmann K, Dahinden C et al. Endotoxins modulate the autocrine function of organ cultured donor corneas and increase the incidence of endothelial cell death. Br J Ophthalmol 1997; 81: 1093-1098.

10 Grabner G, Luger TH, Smolin G et al. Corneal epithelial cellderived thymocyte-activating factor. Invest Ophthalmol Vis Sci 1982; 23: 757-763.

11 Elner VM, Strieter RM, Pavilak MA et al. Human corneal interleukin-8. IL-1 and TNF-induced gene expression and secretion. Am J Pathol 1991; 139: 977-988.

12 Sakamoto S, Inada K. Human corneal epithelial, stromal and endothelial cells produce interleukin-6. Nippon Ganka Gakkai Zasshi 1992; 96: 702-709.

13 Sobottka Ventura AC, Engelmann K, Böhnke M. Fetal calf serum protects cultured porcine corneal endothelial cells from endotoxin-mediated cell damage. Ophthalmic Res 1999; 31: $416-425$.

14 Hudde T, Reinhard T, Möller M, Schelle C, Spelsberg H, Cepin A et al. Korneosklerale transplantatentnahme an der Leiche. Ophthalmologe 1997; 94: 780-784.

15 Thorpe TC, Wilson ML, Turner JE, DiGuiseppi JL, Willert M, Mirrett S et al. BacT/Alert: an automated colorimetric microbial dectection system. J Clin Microbiol 1990; 28: 1608-1612.

16 Snyder JW, Benzing KS, Munier GK, Bostic GD, Bozigar PS, Hanna R et al. Clinical comparison of nonvented aerobic
BacT/Alert blood culture bottle and standard aerobic bottle for detection of microorganisms in blood. J Clin Microbiol 2000; 38: 3864-3866.

17 Roth RI, Levin J, Behr S. A modified Limulus amebocyte lysate test with increased sensitivity for detection of bacterial endotoxin. J Lab Clin Med 1989; 114: 306-311.

18 Roth RI, Levin FC, Levin J. Optimization of detection of bacterial endotoxin in plasma with the Limulus test. J Lab Clin Med 1990; 116: 153-161.

19 Hoffmann F. Perforierende Keratoplastik mit Kreuzstichnaht. Erste Ergebnisse. Klin Monatsbl Augenheilk 1978; 173: 696-700.

20 Reinhard T, Hutmacher M, Sundmacher R. Akute und chronische Immunreaktionen nach perforierender Keratoplastik mit normalem Immunrisiko. Klin Monatsbl Augenheilkd 1997; 210: 139-143.

21 Landesz M, Siertsema JV, Van Rij G. Comparative study of three semiautomated specular microscopes. J Cataract Refract Surg 1995; 21: 409-416.

22 Böhringer D, Reinhard T, Spelsberg H, Sundmacher R. Influencing factors on chronic endothelial cell loss characterised in homogeneous group of patients. $\mathrm{Br} J$ Ophthalmol 2002; 86: 35-38.

23 Ing JJ, Ing HH, Nelson LR, Hodge DO, Bourne WM. Ten-year postoperative results of penetrating keratoplasty. Ophthalmology 1998; 105: 1855-1865.

24 Nishimura JK, Hodge DO, Bourne WM. Initial endothelial cell density and chronic endothelial cell loss rate in corneal transplants with late endothelial failure. Ophthalmology 1999; 106: 1962-1965.

25 Bourne WM, Hodge DO, Nelson LR. Corneal endothelium five years after transplantation. Am J Ophthalmol 1994; 118: 185-196.

26 Ruusuvaara P. Histocompatibility and corneal graft endothelium. Acta Ophthalmol 1979; 57: 968-981.

27 Müller MC, Jacobsen U, Michels G et al. Organ culture of pig cornea: biochemical analyses of mid-term-stored corneal tissue. Ophthalmic Res 1988; 20: 44-53.

28 Redbrake C, Becker J, Salla S et al. The influence of the cause of death and age on human corneal metabolism. Invest Ophthalmol Vis Sci 1994; 35: 3553-3556.

29 Engelmann K, Friedl P. Optimization of culture conditions for human corneal endothelial cells. In vitro Cell Develop Biol 1989; 25: 1065-1072.

30 Kim MK, Palestine AG, Nussenblatt RB et al. Expression of class II antigen in endotoxin induced uveitis. Curr Eye Res 1986; 5: 869-876. 